\title{
The damage caused by Callosobruchus maculatus on cowpea grains is dependent on the plant genotype
}

\author{
Elida Barros Torres, ${ }^{a}$ Rafaela S A Nóbrega, ${ }^{b}$ Paulo Ivan Fernandes-Júnior, ${ }^{c}$ \\ Luciana Barboza Silva, ${ }^{a *}$ Gabriel dos Santos Carvalho, ${ }^{\mathrm{a}}$ Rita de Cassia Nunes \\ Marinho a and Bruno E Pavan ${ }^{\mathrm{d}}$
}

\begin{abstract}
BACKGROUND: Beans from cowpea cultivars fertilized with mineral $\mathrm{N}$ or inoculated with various rhizobium strains may contain different nitrogen concentrations and nitrogen metabolite composition, which affects the beans' defense mechanisms against pests. In this study, the population growth of Callosobruchus maculatus reared on beans from four cowpea cultivars fertilized with different nitrogen sources was evaluated. The factors tested were beans from four cowpea cultivars and seven different nitrogen sources: mineral $\mathbf{N}$ fertilization, inoculation with five strains of symbiotic diazotrophic bacteria, and soil nitrogen (absolute control).

RESULTS: BRS Tapaihum and BRS Acauã cultivars had lower cumulative emergence and instantaneous rate of population growth of the insects compared with other cultivars, indicating antixenosis resistance against C. maculatus. Inoculation of BRS Acauã cultivar with the diazotrophic bacteria strain BR 3299 resulted in higher mortality of C. maculatus. For BRS Tapaihum cultivar, inoculation with diazotrophic bacteria strains BR3267, BR 3262 and BR 3299, and nitrogen fertilization resulted in higher mortality among C. maculatus.
\end{abstract}

CONCLUSION: BRS Tapaihum and BRS Acauã cultivars showed the lowest cumulative insect emergence and instantaneous rates of population growth, and the highest insect mortality, mainly when the grains were obtained from plants inoculated with rhizobial strains.

(C) 2016 Society of Chemical Industry

Keywords: inoculation; nitrogen fertilization; stored grain

\section{INTRODUCTION}

Cowpea [Vigna unguiculata (L.) Walp] (Fabaceae) is an important low-cost and high-quality protein source, especially in tropical regions such as Africa, South America and Central America. In Brazil, this legume is very important to the production systems, mainly those small farmers with family-based systems in the north-east and north regions. For Piauí State, cowpea is the second most economically important legume, occupying an area of 232000 ha with 44000 tons produced in the year 2012. ${ }^{1,2}$

Inoculation of cowpea seeds with commercial inoculants helps to establish plants in the field and can increase grain yield. ${ }^{3-6}$ Recent studies performed in the north-east region of Brazil, inoculation of cowpeas with efficient nitrogen-fixing rhizobia strains resulted in yields similar to those observed with nitrogen fertilization, indicating that the use of inoculants is an alternative nitrogen source for cowpea producers of this region. ${ }^{7-10}$

A portion of the grains and seeds produced in each harvest cannot be used, mainly due to pest attacks during storage. Callosobruchus maculatus is considered the main pest of stored cowpeas because it causes quantitative and qualitative losses when the insect larvae enter the beans and leave behind droppings and eggs. ${ }^{711}$ Farmers use chemicals for $C$. maculatus control; however, these methods may present risks for human health and carry a risk of re-infestation by the pest due to the development of resistant populations. $^{7}$

Weevil resistance has been studied in several cowpea cultivars. 8 ,12-14 These studies have mostly focused on the identification of cultivars that have developed $C$. maculatus resistance due to trypsin and $\beta$-amylase inhibitors. ${ }^{15}$ The identification of cowpea resistance sources and their specific defense compounds is important in the determination of which genetic improvements

\footnotetext{
* Correspondence to: Luciana Barboza Silva, Crop Sciences Department, Federal University of Piauí, Campus Professora Cinobelina Elvas, Bom Jesus, Piauí 64900-000, Brazil.E-mail: lubarbosabio@hotmail.com

a Crop Sciences Department, Federal University of Piauí, Campus Professora Cinobelina Elvas, Bom Jesus, Piauí, Brazil

b Agricultural, Environmental and Biological Sciences Center, Federal University of Recôncavo da Bahia, Cruz das Almas, Bahia, Brazil

c Embrapa Semiárido, Petrolina, Pernambuco, Brazil
}

d Agronomy Department, UNESP, Campus de Ilha Solteira, Sao Paulo, Brazil 
could be made to obtain C. maculatus-resistant plants. ${ }^{16}$ Grains from cowpea cultivars fertilized with mineral $\mathrm{N}$ or inoculated with rhizobial strains may have different nitrogen metabolite concentrations and compositions. Increasing the nitrogen availability in legumes may result in higher production of defense molecules, such as flavonoids, alkaloids, terpenes and sterols, which would in turn bolster the defense mechanisms against pests and result in beans with different levels of resistance against C. maculatus. ${ }^{20}$

The goal of the present study was to evaluate the population parameters of C. maculatus in grains of four different cowpea cultivars that were inoculated with different rhizobial strains or fertilized with mineral nitrogen for testing the hypothesis: cowpea beans from plants fertilized with different sources of nitrogen are more resistant to attack or are susceptible to C. maculatus.

\section{MATERIAL AND METHODS}

For this experiment we used four cowpea cultivars: BRS Acauã, BRS Tapaihum, BRS Pujante and BRS Carijó. When the seed were sown in the field, they were inoculated with one of the following strains of diazotrophic bacteria: BR 3267 (SEMIA 6463), BR 3262 (SEMIA 6464), BR 3299, INPA 03-11B (SEMIA 6462), or UFLA 03-84 (SEMIA 6461). Two non-inoculated control treatments were also performed: one with urea fertilization $\left(80 \mathrm{~kg} \mathrm{~N} \mathrm{ha}^{-1}\right.$ split into two applications, one at planting and one 30 days following seedling emergence) and an absolute control without fertilization or inoculation with rhizobia. The field experiment was conducted at the Mandacaru Experiment Station, Juazeiro, Bahia state (BA), Brazil, at the Embrapa Semiárido premises.

Following harvest, beans were placed in plastic bags and were left at $-20^{\circ} \mathrm{C}$ for 15 days to eliminate infestations arising from the field. Prior to conducting the experiment, the beans were removed from the freezer, placed in plastic containers, covered with voile fabric and kept in the laboratory for 6 days to allow the seeds to reach the hygroscopic balance for each cultivar.

Insects were obtained from a breeding stock and kept in closed $3 \mathrm{~L}$ plastic containers with perforated lids. The containers were wrapped with voile fabric to allow gas exchange and avoid the escape of insects or entrance of undesirable biological agents and were kept at $27 \pm 2{ }^{\circ} \mathrm{C}, 60 \pm 5 \%$ relative humidity with a 12 -h photoperiod. Insects were fed cowpea grains (Vigna unguiculata) that originated from producers from the Bom Jesus municipality, Piauí.

The beans were exposed to the 28 treatments (four cultivars and seven nitrogen sources) were tested for $C$. maculatus resistance by performing a no-choice assay and analyzing the population growth. The bioassay was performed in plastic jars that were $10 \mathrm{~cm}$ in diameter and $6 \mathrm{~cm}$ in height. The lids of the jars were perforated and wrapped in voile fabric to enable ventilation. One hundred grams of cowpea beans from the different treatments and 20 non-sexed adult insects with ages ranging from 1 to 5 days were placed in each jar.

After 60 days, the jars were opened, and the following variables were quantified: number of emerged insects (alive and dead), final grain mass, consumed bean mass and instantaneous rate of population growth $\left(r_{\mathrm{i}}\right)$, which was calculated according to the following equation: ${ }^{17} r_{\mathrm{i}}=\left[\ln \left(N_{\mathrm{f}} / N_{\mathrm{o}}\right)\right] / \Delta t$, where $N_{\mathrm{f}}$ is the final number of insects, $N_{\mathrm{o}}$ is the initial number of insects, and $\Delta t$ is the time interval in days. A positive value of $r_{\mathrm{i}}$ indicates population growth, $r_{\mathrm{i}}=0$ indicates stable population, and a negative $r_{\mathrm{i}}$ indicates population decline heading towards extinction.
The experimental design was completely randomized with a $4 \times 7$ factorial scheme, with four replicates per treatment. The factors tested were beans from four cowpea cultivars (BRS Acauã, BRS Tapaihum, BRS Carijó and BRS Pujante), and seven different nitrogen sources: mineral $N$ fertilisation, inoculation with symbiotic diazotrophic bacteria (strains BR 3267, BR 3262, BR 3299, INPA 03-11B and UFLA 03-84), and soil nitrogen (absolute control, without fertilization or inoculation with rhizobial strains). The data were subjected to an analysis of variance. Interactions between treatments were tested using an $F$ test, and averages were compared using the SNK test with using the SAS 8.02 software. ${ }^{18}$ The differences were considered significant when $P<0.05$.

\section{RESULTS AND DISCUSSION}

A significant effect was observed on the cumulative insect emergence, absolute dry biomass consumed and instantaneous rate of population growth between different cowpea cultivars and conditions. A significant interaction between cultivars and nitrogen sources was observed for the cumulative insect survival and mortality (Table 1).

Regarding the cowpea genotype, BRS Acauã and BRS Tapaihum cultivars had a negative effect on insect development, resulting in decreased cumulative emergence (Table 2). The remaining tested cultivars supported insect emergence and may provide favorable conditions for insect development. The decreased insect emergence may result from high larvae mortality caused by proteins with insecticidal potential, such as vicilin, which is present in some legumes. ${ }^{14}$ Higher emergence of adult insects results in higher quantitative damage, loss of bean nutritional quality, and negative effects on bean appearance, which makes them unsuitable for commercialization and consumption. The results of this study indicate that BRS Acauã and BRS Tapaihum cultivars exhibited antixenosis resistance, or non-preference, to the pests, similar to what was observed for the BRS Nova Era cultivar with Zabrotes subfascuatus. ${ }^{19}$

A loss of mass in stored beans is an important parameter to measure both from an economical point of view and as an indicator of cultivar resistance to pests. ${ }^{20}$ This measure was positively correlated with the number of emerged insects, i.e. higher emergence resulted from higher consumption, or negatively correlated with the presence of substances capable of inhibiting the consumption of the seed interior by C. maculates. ${ }^{21}$ As reported in the literature, the high levels of trypsin inhibitors are responsible for resistance against $C$. maculatus.

The lowest instantaneous rates of population growth were observed for BRS Acauã and BRS Tapaihum cultivars and these rates were significantly different from the other cultivars tested $(P<0.05)$ (Table 2). The instantaneous rate of population growth was positive for all tested cultivars, indicating that they were susceptible to attack by C. maculatus. ${ }^{17}$ However, for this variable, the cultivars BRS Acauã and BRS Tapaihum showed lower levels than for the other plant genotypes, pointing out these genotypes as less susceptible to $C$. maculatus infestation then the other two cultivars evaluated in this study. This lower instantaneous rate of population growth, observed with the data from this study, was probably due to the presence of substances in the grains that inhibit insect feeding, such as arcelin or vicilin, as expressed in the literature. ${ }^{19}$

A significant interaction $(P<0.05)$ between cultivars and inoculation was observed for the cumulative insect survival and mortality (Table 1). The lowest values of cumulative insect survival after 
Table 1. ANOVA of biological parameters of Callosobruchus maculatus reared for 60 days on beans from different cowpea cultivars that were either inoculated with different strains of nitrogen fixing bacteria or were not inoculated (controls)

\begin{tabular}{|c|c|c|c|c|c|c|}
\hline FV & $d f$ & $\begin{array}{c}\text { Cumulative } \\
\text { emergence (absolute } \\
\text { number) }\end{array}$ & $\begin{array}{l}\text { Cumulative survival } \\
\text { (absolute number) }\end{array}$ & $\begin{array}{l}\text { Cumulative mortality } \\
\text { (absolute number) }\end{array}$ & $\begin{array}{l}\text { Consumed dry } \\
\text { biomass (g) }\end{array}$ & $\begin{array}{l}\text { Instantaneous rate of } \\
\text { population growth, } r_{\mathrm{i}}\end{array}$ \\
\hline${ }^{\mathrm{a}} \mathrm{Cul}(\mathrm{C})$ & 3 & $1723014^{*}$ & $10093474^{* *}$ & $10049471^{* *}$ & $1462.43^{* *}$ & $0.000206^{*}$ \\
\hline${ }^{b} \mathrm{~N}(\mathrm{~T})$ & 6 & $938580^{\mathrm{NS}}$ & $476629.26^{*}$ & $1482800.7^{* *}$ & $5.95^{\mathrm{NS}}$ & $0.000069^{\mathrm{NS}}$ \\
\hline$C^{*} T$ & 18 & $597433^{\mathrm{NS}}$ & $758085.6^{* *}$ & $712044.0^{*}$ & $76.76^{\mathrm{NS}}$ & $0.000063^{\mathrm{NS}}$ \\
\hline Error & 111 & 511646 & 195628.3 & 366106.3 & 59.81193 & 0.0000539 \\
\hline $\mathrm{CV} \%$ & - & 38.3 & 45.6 & 68.1 & 14.9 & 9.9 \\
\hline Average & - & 1869.6 & 969.4 & 889.1 & 51.8 & 0.0741 \\
\hline
\end{tabular}

Table 2. Biological parameters of Callosobruchus maculatus reared for 60 days on beans from different cowpea cultivars in a no-choice assay: Bom Jesus, PI 2013

\begin{tabular}{|lccc|} 
Cultivar & $\begin{array}{c}\text { Cumulative } \\
\text { emergence } \\
\text { (absolute number) }\end{array}$ & $\begin{array}{c}\text { Consumed } \\
\text { biomass (g) }\end{array}$ & $\begin{array}{c}\text { Instantaneous rate of } \\
\text { population } \\
\text { growth, } r_{\mathrm{i}}\end{array}$ \\
\hline BRS Acauã & $1698.9^{\mathrm{ab}}$ & $53.0^{\mathrm{a}}$ & $0.073^{\mathrm{ab}}$ \\
BRS Tapaihum & $1620.7^{\mathrm{b}}$ & $41.3^{\mathrm{b}}$ & $0.071^{\mathrm{b}}$ \\
BRS Carijó & $2027.1^{\mathrm{a}}$ & $56.7^{\mathrm{a}}$ & $0.077^{\mathrm{a}}$ \\
BRS Pujante & $2131.7^{\mathrm{a}}$ & $56.4^{\mathrm{a}}$ & $0.076^{\mathrm{a}}$ \\
\hline $\begin{array}{l}\text { a,b Averages followed by the same letter within the same column were } \\
\text { not significantly different according to the SNK test, with a cut-off of } \\
P<0.05 .\end{array}$ \\
\hline
\end{tabular}

60 days of storage were observed for BRS Acauã with urea fertilization and the non-fertilized and non-inoculated controls. For BRS Tapahium, the lowest cumulative insect survival was observed for grains from plants inoculated with the strains BR 3262 and BR 3267 (Table 3). The results obtained with this work indicate that the sources of nitrogen supply used here (inoculation with rhizobia strains or nitrogen fertilization) had an hormoligosis effect on survival of C. maculatus.

BRS Acauã and BRS Tapaihum cultivars were the most resistant against $C$. maculatus, as indicated by the cumulative insect emergence and instantaneous rate of population growth (Table 2). It is worth noting that there was an increased mortality of C. maculatus when cowpea beans from BRS Acauã cultivar were inoculated with the diazotrophic bacteria strain BR 3299. Beans from BRS Tapaihum cultivar inoculated with strains BR3267, BR 3262 and BR 3299 and fertilized with urea also had higher cumulative insect mortality. Non-protein factors, such as tannins and phytic acids, may interfere with the nervous system, hormonal balance and metabolism of the plant's natural enemies, as reported in literature. $^{22}$

The quantity, quality and proportion of nutrients present in the food (including nitrogen) and the presence of secondary or anti-nutritional compounds (allelochemicals) can have various impacts on the biology of insects, which affect their ability to contribute to the next generation and may have sublethal effects. ${ }^{23}$ Furthermore, arcelin was observed to inhibit the development of Zabrotes subfasciatus (Boh.), and vicilin was observed to interfere in the development of C. maculatus. ${ }^{14}$

It should be noted that there were significant differences in the grain $\mathrm{N}$ concentration between different sources of nitrogen $(P<0.05) .{ }^{9}$ Thus, applying bacterial inoculation as a nitrogen source may be associated with changes in cowpea nutrition and may stimulate the production of defense substances in the grains. It may be stated that the quantity and quality of the soluble nitrogen compounds produced depend on the nitrogen source and that different sources will induce variable levels of plant resistance to pests. ${ }^{24}$

Plant nutrition may also result in bean tegmental resistance. The tegument is where the attack by bruchids starts and is a physical line of defense against infestation. Research results reported that differences in plant teguments resulted in varied rates of larvae eclosion and adult emergence and the time needed for the larvae to perforate the tegument..$^{25}$

Insects completely depend on resources acquired during the larval stages for survival and reproduction. ${ }^{26,27}$ The decreased survival of adult insects observed in the present study therefore indicates possible resistance of cowpea cultivars to C. maculatus larvae. It should be highlighted that the higher insect mortality observed for cultivars BRS Acauã and BRS Tapaihum when provided with certain nitrogen sources should be further studied given that inoculation with diazotrophic bacteria, in addition to decreasing production costs and the environmental impacts of nitrogen fertilization, can also be used for pest control, thereby decreasing the use of pesticides.

\section{CONCLUSIONS}

The infestation caused by $C$. maculatus was dependent on the cowpea cultivars and nitrogen sources. BRS Tapaihum and BRS Acauã cultivars showed the lowest cumulative insect emergence and instantaneous rates of population growth, and the highest insect mortality, mainly when the grains were obtained from plants inoculated with rhizobial strains.

\section{REFERENCES}

1 Oliveira GB, Kunz D, Peres TV, Leal RB, Uchôa AF, Samuel R, et al., Variant vicilins from a resistant Vigna unguiculata lineage (IT81D-1053) 
Table 3. Cumulative insect survival and mortality (average) of C. maculatus adults reared for 60 days on beans from different cowpea cultivars that were either inoculated with different strains of nitrogen fixing bacteria or non-inoculated (controls)

bNitrogen source

\begin{tabular}{|c|c|c|c|c|c|c|c|}
\hline \multirow[b]{2}{*}{${ }^{\mathrm{a} C}$ Cutivar } & \\
\hline & BR 3267 & BR 3262 & BR 3299 & UFLA 03-84 & INPA 03-11B & $\mathrm{C} / \mathrm{N}$ & N soil \\
\hline \multicolumn{8}{|c|}{ Cumulative insect survival } \\
\hline BRS Acauã & $1024^{\mathrm{Ab}}$ & $1303.3^{\mathrm{Ab}}$ & $904.0^{\mathrm{Aa}}$ & $1550.5^{\mathrm{Aa}}$ & $1545.5^{\mathrm{Aa}}$ & $184.8^{B C}$ & $63.8^{B C}$ \\
\hline BRTapaihum & $141.0^{B C}$ & $248.3^{B C}$ & $928.3^{\mathrm{ABa}}$ & $883.3^{\mathrm{Aba}}$ & $908.0^{\mathrm{Aba}}$ & $887.0^{\mathrm{ABb}}$ & $1469^{\mathrm{Aa}}$ \\
\hline BRS Carijó & $2068^{\mathrm{Aa}}$ & $1867.0^{\mathrm{Aa}}$ & $1768.8^{\mathrm{Aa}}$ & $1857.0^{\mathrm{Aa}}$ & $1518.0^{\mathrm{A}} \mathrm{a}$ & $1570.3^{\mathrm{Aa}}$ & $1903^{\mathrm{Aa}}$ \\
\hline BRS Pujante & $218.5^{A c}$ & $148.5^{\mathrm{Ac}}$ & $759.0^{\mathrm{Aa}}$ & $614.0^{\mathrm{Aa}}$ & $104.3^{\mathrm{Ab}}$ & $123.8^{\mathrm{Ac}}$ & $581^{\mathrm{Ab}}$ \\
\hline \multicolumn{8}{|c|}{ Cumulative insect mortality } \\
\hline BRS Acauã & $453.8^{\mathrm{Cb}}$ & $361.8^{\mathrm{Cb}}$ & $2092.3^{\mathrm{Aa}}$ & $48.3^{\mathrm{Db}}$ & $32.0^{\mathrm{Db}}$ & $1187.0^{\mathrm{Bab}}$ & $1166^{\mathrm{Ba}}$ \\
\hline BRSTapaihm & $122^{\mathrm{Aab}}$ & $914.3^{\mathrm{Aab}}$ & $1164^{\text {Aab }}$ & $411.8^{\mathrm{Bab}}$ & $515.8^{\mathrm{Bb}}$ & $1177^{\text {Aab }}$ & $515.8^{\mathrm{Bb}}$ \\
\hline BRS Carijó & $294^{\mathrm{ABb}}$ & $138.0^{\mathrm{Cb}}$ & $235.2^{\mathrm{BCb}}$ & $310.5^{\text {Aab }}$ & $144.5^{\mathrm{Cb}}$ & $412.0^{\mathrm{Ab}}$ & $218^{\mathrm{Bbc}}$ \\
\hline BRS Pujante & $1803^{\mathrm{Aa}}$ & $1872.3^{\mathrm{Aa}}$ & $1743.8^{\mathrm{Aa}}$ & $855.3^{\mathrm{Aa}}$ & $2151.5^{\mathrm{Aa}}$ & $2063^{\mathrm{Aa}}$ & $1383^{\mathrm{Aa}}$ \\
\hline
\end{tabular}

Two types of controls were utilised: with or without the addition of mineral nitrogen. Bom Jesus, PI 2013.

Averages followed by the same upper-case letter within the same row and lower-case letter within the same column were not significantly different according to the SNK test, with a cut-off of $P<0.05$.

a Cowpea cultivars: BRS Acauã, BRS Carijó, BRS Pujante and BRS Tapaihum.

${ }^{b}$ Nitrogen source: diazotrophic bacteria strains (BR 3262, BR 3267, UFLA 03-84, INPA 0311B and BR 3299), mineral nitrogen (C/N) and soil nitrogen (control).

accumulate inside Callosobruchus maculatus larval midgut epithelium. Comp Biochem Physiol B 168:45-52 (2014).

2 Instituto Brasileiro de Geografia e Estatística (IBGE), Levantamento Sistemático de Produção Agrícola [Systematic Survey of Agricultural Production] Piauí (2013). Available: <http://www.ibge.gov.br/ home/estatistica/indicadores/agropecuaria/lspa. [July 2013].

3 Martins LMV, Rangel FW, Xavier GR, Ribeiro JRA, Morgado LB, Neves $M C P$, et al., Contribution of biological nitrogen fixation to cowpea: a strategy for improving grain yield in the semi-arid region of Brazil. Biol Fertil Soil 38:333-339 (2003).

4 Fernandes JPI, Silva Júnior EB, Silva Júnior S, Santos CERS, Oliveira PJ, Rumjanek NG, et al., Performance of polymer compositions as carrier to cowpea rhizobial inoculant formulations: survival of rhizobia in pre-inoculated seeds and field efficiency. Afr J Biotechnol (Nairobi) 11:2945-2951 (2012).

5 Ferreira LVM, Nóbrega RSA, Nóbrega JCA, Aguiar FL, Moreira FMS and Pacheco LP, Biological nitrogen fixation in production of Vigna unguiculata (L.) Walp, family farming in Piauí, Brazil. J Agric Sci 5:153-160 (2013).

6 Martins JCR, Freitas ADS, Menezes RSC and Sampaio EVSB, Nitrogen symbiotically fixed by glicidia and cowpea in an agroforestry system in semiarid Northeast Brazil. Pesquisa Agropecuárea Brasileira 50:178-184 (2015).

7 Almeida ALG, Alcântara RMCM, Nóbrega RSA, Nóbrega JCA, Leite IFC and Silva JAL, Produtividade do feijão-caupi cv BR 17 Gurguéia inoculado com bactérias diazotróficas simbióticas no Piauí [Cowpea cv BR17 Gurguéia yield inoculated with symbiotic diazotrophic bacteria in Piauí]. Revista Brasileira de Ciências Agrárias 5:364-369 (2010).

8 Costa EM, Nóbrega RSA, Martins LV, Amaral FHC and Moreira FMS, Nodulação e produtividade de Vigna unguiculata (L.) Walp. por cepas de rizóbio em Bom Jesus, PI [Yield and nodulation of Vigna unguiculata (L.) Walp. inoculated with rhizobia strains in Bom Jesus, PI]. Revista Ciência Agronômica 42:1 -7 (2011).

9 Marinho RCC, Nobrega RSA, Zilli JE, Xavier GR, Santos CAF, Aidair $\mathrm{ST}$, et al., Field perfomace of new cowpea cultivars inoculated with efficient nitogen-fixing rhizobial strains in the Brazilian Semiarid. Pesquisa Agropecuária Brasileira 49:395-402 (2014).

10 Alcantrara RMCM, Xavier GR, Rumjanek NG, Rocha MM and Carvalho JS, Eficiência simbiótica de progenitores de cultivares brasileiras de feijão-caupi. Revista Ciência Agronômica 45:1-19 (2014).

11 Sousa AH, Maracajá PB, Silva RMA, Moura AMN and Andrade WG, Bioactivity of vegetal powders against Callosobruchus maculatus (Coleoptera: Bruchidae) in caupi bean and seed physiological analysis. Revista de Biologia and Ciências da Terra 5:1519-5228 (2005).

12 Wanderley VS, Oliveira JV and Andrade Jr ML, Resistência de cultivares e linhagens de Phaseolus vulgaris L. a Zabrotes subfasciatus (Boh.)
(Coleoptera: Bruchidae) [Resistance of cultivars and lines of bean, Phaseolus vulgaris L., to Zabrotes subfasciatus (Boh.) (Coleoptera: Bruchidae)]. da Sociedade Entomológica do Brasil 26:315-320 (1997).

13 Barreto PD and Quinderé AW, Resistência de genótipos de caupi ao caruncho [Resistance of cowpea genotypes to Callosobruchus maculatus]. Pesquisa Agropecuária Brasileira 35:779-785 (2000).

14 Domingues SJS, Melo FR, Aguiar JM, Affonso AG, Giuli JSA, Rose JL, et al., Resistance of Vigna unguiculata (cowpea) seeds to Callosobruchus maculatus is restricted to cotyledonary tissues. I Sci Food Agric 86:1977-1985 (2006).

15 Gatehouse AMR, Gatehouse JA, Dobie P, Kilminster AM and Boutlier D, Biochemical basis of insect resistance in Vigna unguiculata. J Sci Food Agric 30:948-958 (1989).

16 Ndakidemi PA and Dakora FD, Legume seed flavonoids and nitrogenous metabolites as signals and protectants in early seedling development. Funct Plant Biol 30:729-745 (2003).

17 Walthall WK and Stark JD, Comparison of two population-level ecotoxicological endpoints: the intrinsic ( $\mathrm{rm}$ ) and instantaneous (ri) rates of increase. Environ Toxicol Chem 16:1068-1073 (1997).

18 SAS Institute, SAS User's Guide: Statistics v. 8.2. SAS Institute, Cary, NC (2001).

19 Barbosa DRS, Fontes LS, Melo RS, Rocha LíR and Lima MS, Resistência de genótipos de feijão-caupi ao ataque de Zabrotes subfasciatus (Boheman, 1833) (Coleoptera: Chrysomelidae: Bruchinae) [Resistance of cowpea genotypes to attack by Zabrotes subfasciatus (Boheman, 1833) (Coleoptera: Chrysomelidae: Bruchinae)]. Revista Verde 6:70-77 (2011).

20 Potrich $M$, Associação de variedades resistentes de milho e fungos Entomopatogenicos para controle de Sitophilus ssp. [Association of resistant corn varieties and entomopathogenic fungi for the control of Sitophilus ssp.]. MSc thesis. Universidade Estadual do Oeste do Paraná, Marechal Cândido Rodon Campus, Paraná (2006).

21 Costa NP and Boiça JRAL, Efeito de genótipos de caupi, Vigna unguiculata (L.) Walp., sobre o desenvolvimento de Callosobruchus maculatus (Fabricius) (Coleopetar: Bruchidae) [Effect of cowpea genotypes, Vigna unguiculata (L.) Walp., on the development of Callosobruchus maculatus (Fabricius) (Coleoptera: Bruchidae)]. Neotrop Entomol 33:77-83 (2004).

22 Grangeiro TB, Castellón RER, Araújo FMMC, Silva SMS, Freire EA, Cajazeiras JB, et al., Composição bioquímica da semente [Biochemical composition of seeds], in Feijão-caupi: Avanços Tecnológicos ed. by Freire-Filho FR, Lima JAA and Ribeiro VQ. Embrapa Informação Tecnológica, Brasília, DF, pp. 338-365 (2005). 
23 Parra JRP and Panizzi ARA, Bioecologia e a nutrição de insetos como base para o manejo integrado de pragas [Bioecology and insect nutrition as basis for integrated pest management], in Biotecnologia e nutrição de insetos. Base para manejo integrado de pragas, ed. by Panizzi AR and Parra JRP. Embrapa informação tecnológica, Brasília, DF, pp. 1107-1139 (2009).

24 Bortoli AS and Maia IG, Influência da aplicação de fertilizantes na ocorrência de pragas [Influence of fertiliser application on pest occurrence], in Importância Da Adubação Na Qualidade Dos Produtos Agrícolas, ed. by Sá ME and Buzzeti S. São Paulo, Brazil, pp. 53-63 (1994).
25 Souza AJ, Santos PO, Pinto MST, Wermelinger TT, Ribeiro ES, Souza SC, et al., Natural seed coats provide protection against penetration by Callosobruchus maculatus (Coleoptera: Bruchidae) larvae. Crop Protect 30:651-657 (2011).

26 Stearns SC, The Evolution of Life Histories. Oxford University Press, New York, p. 264 (1992).

27 Sarwar M, Assessment of resistance to the attack of bean beetle Callosobruchus maculatus (Fabricius) in chickpea genotypes on the basis of various parameters during storage. Songklanakarin J Sci Technol 34:287-291 (2012). 